\title{
Knowledge Capture and Acquisition Mechanisms at Kisii University
}

\author{
Nemwel N. Aming'a \\ Research and Extension, Kisii University, Kisii, Kenya
}

nemwel.aming'a@kisiiuniversity.ac.ke

\begin{abstract}
Knowledge management and knowledge assets have gained much prominence in recent years and are said to improve organizational performance. Knowledge capture and acquisition mechanisms enhance organizational memory and performance. However, knowledge capture and acquisition mechanisms in higher education institutions are not well known. The aim of this study was to investigate the knowledge capture and acquisition mechanisms at Kisii University. This was a case study in which data were collected through interviews and questionnaires. Purposive sampling was used to determine interview participants while questionnaire respondents were selected through stratified random sampling. Qualitative and quantitative data were analysed using SPSS ${ }^{\circledR}$ student version 14; it revealed that there were various knowledge capture and acquisition mechanisms at Kisii University. It was also established that the University encountered various challenges in knowledge capture and acquisition and lacked some essential knowledge capture and acquisition mechanisms. In this regard, this study proposed knowledge capture and acquisition guidelines that may be adopted by the University to enhance its organizational memory and performance.
\end{abstract}

Keywords: Knowledge Management, Mechanisms, Knowledge Capture and Acquisition mechanisms, knowledge capture and acquisition.

\section{Introduction}

Knowledge management and knowledge assets have gained much prominence in recent years and are said to improve organizational performance. Nonaka (1994) defines knowledge as a justified belief that increases an entity's capacity for effective action. Knowledge should be availed at the right time to the right people for efficient and effective decision making. Most organizations, including higher education institutions, view knowledge as a strategic resource that offers a competitive advantage (Halawi, Aronson, \& McCarthy 2005). Faced with increasing dynamic and competitive environments, organizations have realized that there is a vast and largely untapped

Material published as part of this publication, either on-line or in print, is copyrighted by the Informing Science Institute. Permission to make digital or paper copy of part or all of these works for personal or classroom use is granted without fee provided that the copies are not made or distributed for profit or commercial advantage AND that copies 1) bear this notice in full and 2) give the full citation on the first page. It is permissible to abstract these works so long as credit is given. To copy in all other cases or to republish or to post on a server or to redistribute to lists requires specific permission and payment of a fee. Contact Publisher@,InformingScience.org to request redistribution permission. asset diffused around the organizationknowledge (Gupta, Iyer, \& Aronson 2000). Cranfield (2011) has argued that higher education is undergoing transformations due to a range of external forces such as market competition, virtualization and internalization, giving rise to new ways of understanding the role and functions of a university. Thus, there is a need for organizations to ef- 
fectively manage their knowledge in order to gain a competitive advantage and improve their performance. Despite this realization, not many higher education institutions have started managing knowledge efficiently and effectively (Kruger \& Snyman, 2005).

Knowledge management entails activities such as knowledge creation, identification, acquisition, capture, storage, development, sharing, retrieval, dissemination, utilization, and retention. Probst, Raub, and Romhardt (2000) contend that knowledge management entails knowledge identification, acquisition, development, sharing and distribution, utilization and retention. This paper focuses on knowledge capture and acquisition mechanisms. The key to strategic decision making lies in the fact that institutions are able to capture and acquire necessary knowledge for informed decision making. Knowledge capture and acquisition mechanisms are said to build organizational memory, thus leading to improved organizational performance. However, little research has been done to establish the knowledge capture and acquisition mechanisms in various higher education institutions in Kenya.

\section{Literature Review}

\section{Knowledge Capture and Acquisition Mechanisms}

Since their inception, higher education institutions, particularly universities, have been perceived as knowledge creators, inventors, generators, and distributors. In this regard, their core mandates has been teaching, training and research. Davenport and Prusak (1998) defined knowledge management as the processes which support knowledge collection, sharing, and dissemination. In the current global knowledge economy, universities must focus on creating, capturing, and acquiring knowledge with the view of retaining their knowledge for enhanced organizational performance. There are instances of knowledge loss through aging workforce, staff transfer to different positions within the organization, loss of knowledge when public lectures and conference proceedings are not captured, staff resignation, and inefficient operating procedures. Due to these challenges, universities require efficient and effective knowledge capture and acquisition mechanisms to prevent knowledge loss and build organizational memory. This way, higher education institutions will be able to gain a competitive advantage, and improve organizational performance.

According to Schwartz and Brasethvik (2000) knowledge acquisition is concerned with how to collect knowledge from members of the organization or other sources and store that knowledge in an organizational memory. A knowledge acquisition process in an organization aims at obtaining knowledge from both internal and external sources. This knowledge is then developed to enhance the organizations competitive edge through increasing an organization's operational knowledge base. Knowledge acquired can either be tacit or explicit but must add value to the organization. Knowledge capture is the ability of the organization to ensure that knowledge available is stored for future reference in either databases or manuals. Wagner and Zubey (2005) indicated that interviews, protocol analysis, and card sorting were among the many knowledge acquisition mechanisms in various organizations. The following knowledge capture and acquisition mechanisms have been identified.

\section{Recruitment}

Recruitment is the finding and hiring the right people for jobs in the organization with specific emphasis on filling certain knowledge gaps (Schofield, 2008). Organizations should recruit employees based on the knowledge gap within their workforce. 


\section{Training}

Continuous employee training enhances the acquisition of new skills in an organization. Training empowers employees to feel confident about themselves as well as motivating them to work even harder and be involved in the decision making process. Training should be based on the required skills by employees to perform necessary tasks within their daily duties.

\section{Expert systems}

Tacit knowledge from experts is captured and stored in systems known as expert systems. In the expert systems, the knowledge is preserved and can be used for future reference when the experts have left the organization. This way, the institutional memory is improved and retained.

\section{Brainstorming}

Liou (1990) explains that brainstorming is a group method for developing ideas and exploring their meaning. Brainstorming occurs in boardrooms where meetings are held; through deliberations, ideas are exchanged and new knowledge is generated in the process. The new knowledge generated usually in tacit form is captured inform of minutes and can be used to drive change in the organization.

\section{Mentoring}

Mentoring is a process that occurs when a more experienced employee offers to train a less experienced employee. This process may be formal or informal, and the experienced member of staff is referred to as a 'mentor' and the less experienced member of staff is referred to as a 'protégé'. Mentoring programs in organizations have benefits to the mentor, protégé, and the organization. The protégé acquires professional development and skills from the mentor, while the mentor develops professional relationships and enhances peer recognition and job satisfaction. Mentoring enhances team performance and commitment in an organization.

\section{Knowledge repository}

DeLong (2004) contends that documenting knowledge supports the transfer of knowledge amid changes in workforce demographics and knowledge attrition. Organizations must develop knowledge repositories where they store their knowledge. This prevents loss of knowledge through natural attrition, transfer of staff, and staff leaving the organization.

\section{Interviews}

Interviews are used to capture and acquire knowledge in human resource departments as they engage new employees, when creating knowledge repositories, or when an employee is leaving the organization (Kelleher 2006). Interviews can either be structured or unstructured; the overall aim is to elicit information from the interviewee.

\section{Observation}

This is where a novice observes an expert engage in an activity, especially in problem solving, and documents all the steps in the problem solving process. This way, the novice acquires and captures knowledge from the expert. Knowledge captured can be used in future to solve similar problems. This way, knowledge from experts is retained in the organization.

\section{Importance of Knowledge Capture and Acquisition Mechanisms}

Knowledge capture and acquisition mechanisms are said to be key strategic organizational resources as they enhance organizational memory and performance. Knowledge capture and acqui- 
sition mechanisms, including recruitment, training and development, brainstorming, and subject matter experts, ensure the acquisition and generation of innovative ideas and serve as tools to replace knowledge loss and speed up processes of knowledge acquisition for new employees (Wamundila \& Ngulube, 2011).

Possessing expert systems will enhance accessible guidance for executing organizational operations (Wamundila \& Ngulube, 2011). Similarly, after-action reviews ensure frequent reviews of various actions and provide recommendations on how best to handle organizational tasks and in turn enhance organizational operations (Wamundila \& Ngulube, 2011). Knowledge repositories ensure that knowledge captured and acquired by organizations is available to staff and for future reference and thus prevent organizational knowledge loss.

Knowledge capture and acquisition mechanisms facilitate better decision making due to availability of the right knowledge to the right people at the right time to enhance effective and efficient decision making. Further, they enhance staff turnover control through supporting knowledge capture and transfer.

Kidwell, Vander Linde, and Johnson (2000) contend that knowledge management can benefit educational institutions in at least five areas: research, curriculum development, student and alumni services, administration, strategic planning, and traditional classroom enhancement. Exploratory studies on knowledge management outcomes in Malaysia indicate that the perceived benefits include better decision-making, better understanding of customers, improved skill base, better quality and efficiency, better outputs and innovation, sharing of best practices, and faster response to key institutional issues (Rumesh, 2003).

\section{Challenges in Knowledge Capture and Acquisition}

There are many challenges that hamper the effective capture and acquisition of both tacit and explicit knowledge in an organization. Organizations, especially higher education institutions, lack adequate well trained manpower to capture and acquire knowledge. Mohammad and Al Saiyd (2012) contend that knowledge must be acquired and captured in an organized way; this implies that staff must have the skills to capture knowledge in systematic ways. Experts with experience are not always available, making it difficult for institutions to acquire and capture knowledge necessary for improved organizational performance from experts.

Most higher education institutions in Africa are resource constrained, therefore, they do not have adequate resources to fund knowledge capture and acquisition mechanisms which in most cases are expensive. Mohammad and Al Saiyd (2012) argue that retrieving knowledge from human minds is an expensive process that is time consuming and requires skilled personnel.

Organizations need to implement knowledge management systems to enhance knowledge capture and acquisition processes. Akhavan, Jafari, \& Fathian (2005) conducted research to determine the factors that lead to failure of knowledge management systems. They focused on the following factors: focusing KM efforts only within organizational boundaries, failure to understand and connect KM into individuals daily work activities, creation of repositories without addressing the need to manage content, resistance towards change, organizational culture, lack of familiarity of top management with dimensions of $\mathrm{KM}$ and its requirements and failure to align $\mathrm{KM}$ efforts with organizations strategic objectives (Akhavan et al., 2005). Ambrosio (2000, as cited in Akhavan et al., 2005) noted that the most common error in implementing knowledge management systems is failure to coordinate efforts between information technology and staff. Cooperation among members of staff is another major challenge in knowledge capture and acquisition. If members of staff do not agree which knowledge needs to be captured, then the organization will not be in a position to acquire the necessary knowledge. 


\section{Research Methodology}

This was a case study that was carried out at Kisii University. Questionnaires and interview schedules were used to collect data on knowledge capture and acquisition mechanisms at Kisii University. This study had two sample frames. The first sample frame was to interview participants where members of management and in charge of various departments at the University were purposively selected and interviewed. A total of 12 interviews were conducted. The second sample frame was questionnaire respondents where 250 questionnaires were distributed among members of staff in various departments. Stratified random sampling was used to select questionnaire respondents. The sample size for questionnaire respondents was determined using Yamane's simplified formula (Israel, 2012):

$$
\begin{aligned}
& \mathrm{n}=\mathrm{N} /\left(1+\mathrm{N}(\mathrm{e})^{2}\right) \\
& \mathrm{e}^{2}=0.05^{2}
\end{aligned}
$$

Where:

$$
\begin{aligned}
& \mathrm{n} \text {-the desired sample size } \\
& \mathrm{e}^{2} \text {-the confidence level } \\
& \mathrm{N} \text {-the total population under study }
\end{aligned}
$$

The total population of the study was 680 less 12 who were interviewed bringing the total to 669 . When the formula was applied to the 668 potential respondents, it yielded a sample size of 250 . The sample size of the members of staff was distributed among the various departments using stratified sampling technique.

The total number of received questionnaires was 172 translating to a response rate of $68.8 \%$, which was deemed desirable for data analysis, and a total of 12 interviews were conducted. The statistical package for social sciences (SPSS) student version 14 was used to analyze both qualitative and quantitative data. Qualitative data were content analysed and major themes identified. The themes were coded then analysed. Analysed data were presented in graphs, tables, and descriptions. Reliability coefficient was computed using the Cronbach alpha coefficient. The results showed an alpha coefficient above 0.73 which was acceptable.

\section{Findings and Discussions}

\section{Demographic Characteristics of Respondents}

\section{Respondents' gender}

Table 1: Gender of Respondents

\begin{tabular}{lrr}
\hline Gender & Frequency & Percentage \\
Male & 103 & 55.98 \\
Female & 81 & 44.02 \\
Total & 184 & 100 \\
\hline
\end{tabular}

There were 103 males and 81 females in the study. 


\section{Education of respondents}

Table 2: Education of Respondents

\begin{tabular}{lll}
\hline Level of Education & Frequency & Percentage \\
Certificate & 32 & 17.39 \\
Diploma & 75 & 40.76 \\
Degree & 48 & 26.09 \\
Masters & 21 & 11.41 \\
PhD and Higher & 8 & 4.35 \\
Total & 184 & 100 \\
\hline
\end{tabular}

Based on the results as presented in Table 2, it can be concluded that the majority of the respondents had their level of education at diploma level and above, so they had enough knowledge and skills to give useful insights into the knowledge capture and acquisition mechanisms available at Kisii University.

\section{Respondents' work experience}

Table 3: Work Experience of Respondents

\begin{tabular}{lll}
\hline Work experience in Years & Frequency & Percentage \\
$1-5$ years & 84 & 45.65 \\
6 - 10 years & 56 & 30.43 \\
$11-15$ years & 20 & 10.67 \\
16 years and above & 24 & 13.04 \\
Total & 184 & 100 \\
\hline
\end{tabular}

Based on the results as presented in Table 3, it can be concluded that the majority of the respondents had worked for a long time, so they had enough experience to do their jobs according to expectations and were in a position to give useful insights into the knowledge capture and acquisition mechanisms at Kisii University.

\section{Knowledge Capture and Acquisition Mechanisms}

Both interview and questionnaire respondents agreed that there were knowledge capture and acquisition mechanisms at Kisii University. All interview participants indicated that their departments acquired and captured knowledge through training, recruitment, consultancy, manuals, mobile phones, groupware technologies, flow charts, seminars, notices, meetings, induction, workshops, multimedia, benchmarking with other institutions, field trips, schemes of service, work procedures, work plan, partnerships, staff exchange programmes, and minutes. Two of the interview participants indicated that their departments acquired and captured knowledge through benchmarking, partnerships, and research papers. Questionnaire findings concurred with interview findings as they revealed the availability of various knowledge capture and acquisition mechanisms at Kisii University as indicated in Table 4. These findings were similar to the findings of a study done by Wamundila (2008) at University of Zambia. 
Table 4: Knowledge Capture and Acquisition Mechanisms

\begin{tabular}{lcc}
\hline $\begin{array}{c}\text { Knowledge capture and acqui- } \\
\text { sition mechanisms }\end{array}$ & Number & Percentage \\
\hline Training & 154 & $89.50 \%$ \\
Mentoring & 68 & $39.50 \%$ \\
Knowledge Repository & 24 & $14.00 \%$ \\
Expert systems & 22 & $12.80 \%$ \\
Recruitment & 138 & $80.20 \%$ \\
Brainstorming & 80 & $46.50 \%$ \\
Notices & 154 & $89.50 \%$ \\
\hline
\end{tabular}

Table 5: Statements on Knowledge Capture and Acquisition Mechanisms

\begin{tabular}{|c|c|c|c|c|c|c|}
\hline No & Statement & $\begin{array}{l}\text { Strongly } \\
\text { Agree }\end{array}$ & Agree & $\begin{array}{l}\text { No Opin- } \\
\text { ion }\end{array}$ & Disagree & $\begin{array}{l}\text { Strongly } \\
\text { Disagree }\end{array}$ \\
\hline 1 & $\begin{array}{l}\text { Minutes are taken to cap- } \\
\text { ture ideas during meet- } \\
\text { ings }\end{array}$ & $\begin{array}{l}135 \\
(78.49 \%)\end{array}$ & $\begin{array}{l}31 \\
(18.02 \%)\end{array}$ & $\begin{array}{l}3 \\
(1.74 \%)\end{array}$ & $\begin{array}{l}1 \\
(0.58 \%)\end{array}$ & $\begin{array}{l}2 \\
(1.16 \%)\end{array}$ \\
\hline & $\begin{array}{l}\text { I consult my colleagues } \\
\text { when undertaking my } \\
\text { duties }\end{array}$ & $\begin{array}{l}114 \\
(66.28 \%)\end{array}$ & $\begin{array}{l}40 \\
(23.26 \%)\end{array}$ & $\begin{array}{l}3 \\
(1.74 \%)\end{array}$ & $\begin{array}{l}4 \\
(2.33 \%)\end{array}$ & $\begin{array}{l}11 \\
(6.40 \%)\end{array}$ \\
\hline 3 & $\begin{array}{l}\text { Work manuals and pro- } \\
\text { cedures are prepared for } \\
\text { workers }\end{array}$ & $\begin{array}{l}33 \\
(19.19 \%)\end{array}$ & $\begin{array}{l}36 \\
(20.93 \%)\end{array}$ & $\begin{array}{l}21 \\
(12.21 \%)\end{array}$ & $\begin{array}{l}24 \\
(13.95 \%)\end{array}$ & $\begin{array}{l}58 \\
(33.72 \%)\end{array}$ \\
\hline 4 & $\begin{array}{l}\text { Regular trainings related } \\
\text { to work activities are or- } \\
\text { ganized }\end{array}$ & $\begin{array}{l}46 \\
(26.74 \%)\end{array}$ & $\begin{array}{l}46 \\
(26.74 \%)\end{array}$ & $\begin{array}{l}28 \\
(16.28 \%)\end{array}$ & $\begin{array}{l}27 \\
(15.70 \%)\end{array}$ & $\begin{array}{l}25 \\
(14.53 \%)\end{array}$ \\
\hline 5 & $\begin{array}{l}\text { Databases of good prac- } \\
\text { tices are regularly updat- } \\
\text { ed }\end{array}$ & $\begin{array}{l}32 \\
(18.60 \%)\end{array}$ & $\begin{array}{l}27 \\
(15.70 \%)\end{array}$ & $\begin{array}{l}7 \\
(4.07 \%)\end{array}$ & $\begin{array}{l}32 \\
(18.60 \%)\end{array}$ & $\begin{array}{l}74 \\
(43.02 \%)\end{array}$ \\
\hline 6 & $\begin{array}{l}\text { Employees are recruited } \\
\text { to bring in new } \\
\text { knowledge }\end{array}$ & $\begin{array}{l}63 \\
(36.63 \%)\end{array}$ & $\begin{array}{l}70 \\
(40.70 \%)\end{array}$ & $\begin{array}{l}19 \\
(11.05 \%)\end{array}$ & $\begin{array}{l}10 \\
(5.81 \%)\end{array}$ & $\begin{array}{l}10 \\
(5.81 \%)\end{array}$ \\
\hline
\end{tabular}

As shown in Table 5, on statements on knowledge capture and acquisition, positive responses were received for "minutes are taken to capture ideas during meetings" (96.51\%), "consulting colleagues when undertaking duties" (89.54\%), "regular training related to work activities" $(53.48 \%)$ and "employees are recruited to bring in new knowledge" $(77.33 \%)$. "Databases of good practices are regularly updated" received an overall negative response of $61.62 \%$, and "work manuals and procedures are prepared for workers" received an overall negative response of $47.67 \%$. Based on the analysis of the results, minutes are used to capture knowledge at Kisii University, but the University does not regularly update databases of best practices, which could 
imply that best practices that could be captured for future reference are infrequently adopted at the University, hence knowledge loss. There could also be instances of reinventing the wheel because experiences are not documented.

\section{Challenges in Knowledge Capture and Acquisition}

Results show that Kisii University encountered various challenges in knowledge capture and acquisition. Interview findings revealed the following challenges: three quarters of the twelve respondents indicated that the university encountered financial challenges in its endeavour to acquire and capture knowledge for operational efficiency. This affects the university's ability to recruit competent and qualified personnel, train staff on necessary skills required for job performance, and acquire technology necessary for knowledge capture and acquisition. Two of the participants indicated that it was tricky for the university to release members of staff for training due to shortage of staff, most members of staff opt to study areas not related to their work thus a waste of time and resources, staff also neglected their duties when undertaking long term studies, and removal of notices from notice boards hampered knowledge acquisition which led to poor organizational performance.

One of the participants revealed that it was difficult to select members of staff to attend seminars and trainings due to high competition and that most of the knowledge required did not exist in Kenya; hence, it was difficult to acquire such knowledge and there was a challenge to adapt such new knowledge in the country particularly the agricultural innovations. They also revealed that there was a challenge of knowledge loss with staff leaving. This affected knowledge capture and acquisition as experienced staff left the institution to other institutions; this finding was similar to that of Wamundila and Ngulube (2011) who conducted a study at the University of Zambia and realized that there were inadequate knowledge management practices at the university which led to knowledge loss. Further, they indicated that systems in the department were not computerized, hence difficult to trace the knowledge that has been acquired and captured, which makes it difficult to utilize that knowledge.

Five of the participants indicated that internet breakdown and continuous power fluctuations hampered the knowledge capture and acquisition at Kisii University. This is a challenge encountered by most developing countries. Questionnaire respondents also identified various challenges encountered in knowledge capture and acquisition at the University as indicated in Table 6.

Table 6: Challenges in Knowledge Capture and Acquisition

\begin{tabular}{ll}
\hline Challenge & $\begin{array}{l}\text { Number } \\
\text { (Percentage) }\end{array}$ \\
\hline Inadequate facilities & $44(25.58 \%)$ \\
Inadequate trained man power & $44(25.58 \%)$ \\
Inadequate knowledge resources & $16(9.30 \%)$ \\
Lack of cooperation among members of staff & $18(10.47 \%)$ \\
Some members don't want to acquire new knowledge & $18(10.47 \%)$ \\
Inadequate funds & $18(10.47 \%)$ \\
\hline
\end{tabular}

The questionnaire findings concur with interview findings that Kisii University encountered various challenges in knowledge capture and acquisition. Overall, the challenges encountered inter- 
fered with knowledge capture and acquisition at the University. Lack of adequate operational knowledge will be reflected in inefficiencies and ineffectiveness in service delivery.

\section{Practical Implications}

The findings from this study will be used to develop policy for knowledge capture and acquisition at higher education institutions and especially for Kisii University. This way, there will be improved organizational performance through an improved knowledge base and organizational memory, which will ensure availability of the right knowledge at the right time to the right people for effective decision making, thus improved organizational performance. The proposed guidelines for knowledge capture and acquisition will enhance the adoption of various knowledge capture and acquisition mechanisms, thus improving knowledge retention in Kisii University and other higher education institutions. This study will form a firm foundation for other studies in the field of knowledge management.

\section{Conclusions}

The study established training, brainstorming, recruitment, mentoring, and notices as the most important knowledge capture and acquisition mechanisms at Kisii University. The level of adoption of the knowledge capture and acquisition mechanisms at the University was low; therefore, the university needs to improve its capacity to capture and acquire relevant functional knowledge to enhance organizational memory and thus improve organizational performance.

With a view to combat the established challenges in knowledge capture and acquisition, Kisii University, and in extension other higher education institutions, should adopt the following knowledge capture and acquisition mechanisms to enhance its organizational memory: subject matter experts, after action reviews, and expert systems. These mechanisms together with the mechanisms already at the University will advance and encourage an adequate operational knowledge base and hopefully improve organizational performance.

\section{Recommendations}

Figure 1 illustrates the challenges of knowledge capture and acquisition, strategies and guidelines to overcome these challenges and the potential outcomes of these strategies. Kisii University and other higher education institutions should adopt the proposed knowledge capture and acquisition guidelines. The study also recommends that management should develop a knowledge capture and acquisition strategy that will inculcate the proposed guidelines and training members of staff on the importance of computer literacy.

\section{Suggestions for Further Research}

Other knowledge capture and acquisition mechanisms that were not covered in this study such as storytelling and knowledge decision trees needs to be addressed. Comparative studies need to be carried out in other higher education institutions in the region and internationally to determine the knowledge capture and acquisition mechanisms in those institutions and their level of adoption.

\section{Acknowledgement}

I am grateful to Kisii University for permission to conduct the study. I thank the members of staff at the University for willingly participating and providing information for this study. 


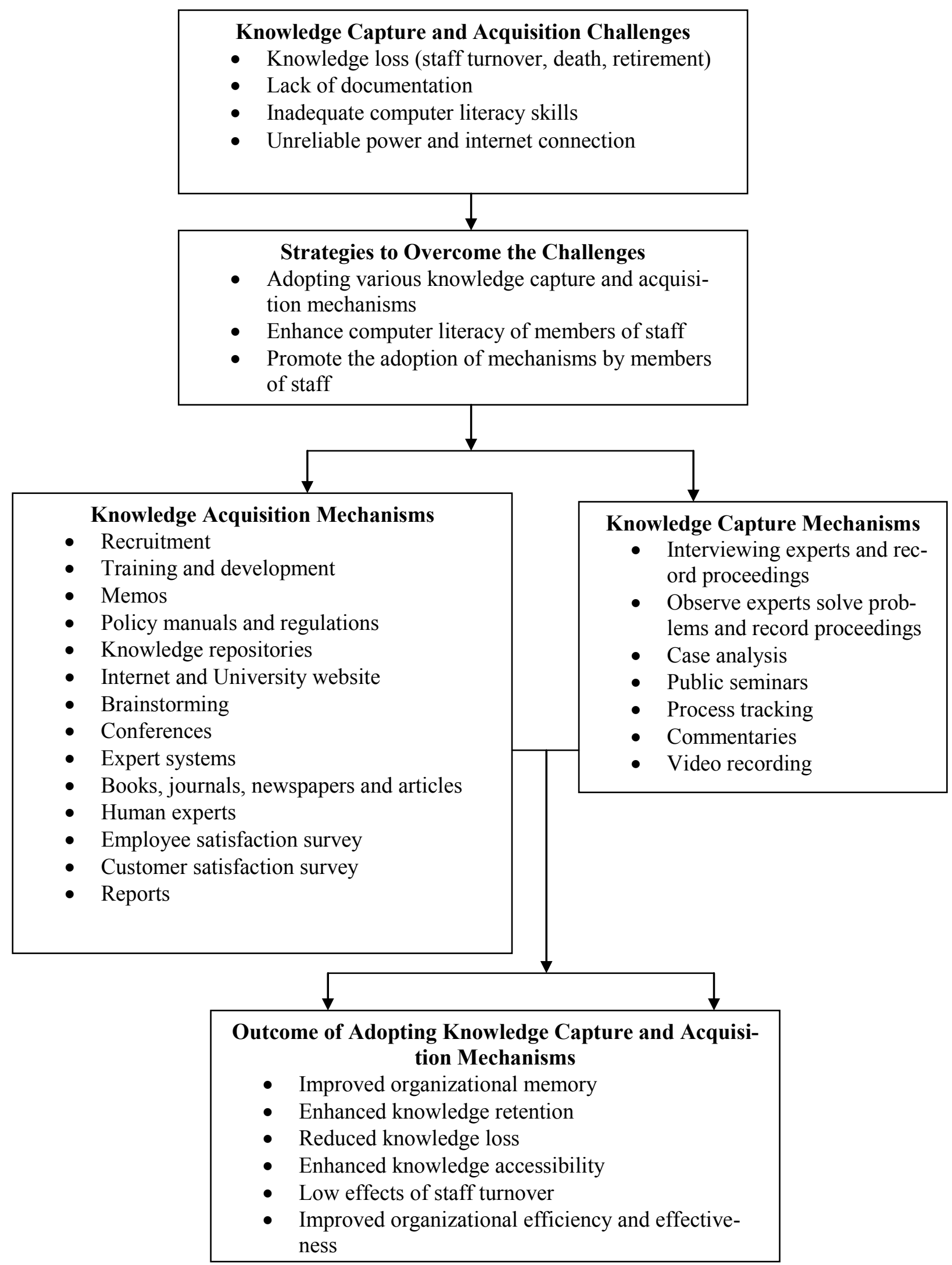

Figure 1: Proposed Knowledge Capture and Acquisition Guidelines 


\section{References}

Akhavan, P., Jafari, M., \& Fathian, M. (2005). Exploring failure factors of implementing knowledge management systems in organizations. Journal of Knowledge Management Practice, 6. Available at http://papers.ssrn.com/sol3/papers.cfm?abstract id=2188273

Cranfield, D. (2011). Knowledge management and higher education: A UK case study using grounded theory. University of Southampton. Retrieved on $22^{\text {nd }}$ March 2012 from http://eprints.soton.ac.uk

Davenport, T., \& Prusak, L. (1998).Working knowledge. Boston: Harvard Business School Press.

DeLong, D. W. (2004). Lost knowledge: Confronting the threat of an aging workforce. New York: Oxford University Press.

Gupta, B., Iyer, L. S., \& Aronson, J. E. (2000). Knowledge management: Practices and challenges. Industrial Management \& Data Systems, 100(1), 17-21. Retrieved on $10^{\text {th }}$ June 2012 from http://www.emeraldinsight.com

Halawi, A. L., Aronson, E. J., \& McCarthy, V. R. (2005). Resource-based view of knowledge management for competitive advantage. The Electronic Journal of Knowledge Management, 3(2), 75-86. Retrieved on $22^{\text {nd }}$ October 2012, from http://www.ejkm.com/volume3/issue2

Israel, G. (2012). Determining sample size. IFAS Extension: University of Florida. Retrieved on $23^{\text {rd }}$ March 2012 from http://edis.ifas.ufl.edu

Kelleher, M. (2006). Knowledge retention: Replacing traditional exit interview. Retrieved $23^{\text {rd }}$ March 2012 from http://www.eclo.org

Kidwell, J., Vander Linde, K., \& Johnson, S. L. (2000). Applying corporate knowledge management practices in higher education. EDUCAUSE Leadership, 4(3) Retrieved on $23^{\text {rd }}$ March 2012 from http://net.educause.edu

Kruger, C. J,. \& Snyman, M. M. M. (2005). Principles and strategies for the effective management of knowledge. Mousaion, 23(1), 62-80.

Liou, Y. (1990). Knowledge acquisition: Issues, techniques, and methodology. In Proceedings of the 1990 ACM SIGBDP conference on Trends and directions in expert systems (pp. 212-236). ACM. Retrieved on October $10^{\text {th }}, 2013$, from http://www.acm.org

Mohammad, A. H., \& Al Saiyd, N. A. M. (2012). Guidelines for tacit knowledge acquisition. Journal of Theoretical and Applied Information Technology, 38(1), 110-118. Retrieved on October $10^{\text {th }}, 2013$, from http://www.jatit.org/volumes/Vol38No1/15Vol38No1.pdf

Nonaka, I. (1994). A dynamic theory of organizational knowledge creation. New York: Oxford University Press.

Probst, G., Raub, S., \& Romhardt, K. (2000). Managing knowledge-Building blocks for success. John Wiley and Sons, UK.

Rumesh, K. (2003). Managing knowledge in turbulent business environments: An empirical study in the Malaysian context. Malaysian Management Review, 38(2), 39-60.

Schofield, D. (2008). Community government human resource development system. Retrieved $23^{\text {rd }}$ March 2012 from http://www.maca.gov.nt.ca/school/tools/CGHRDS\%20Manual\%20.pdf

Schwartz, D. G., \& Brasethvik, T. (2000). Internet-based organization memory and knowledge management. Hershey, PA: Idea Group Publishing.

Wagner, W. \& Zubey, M. (2005). Knowledge acquisition for marketing expert systems based upon marketing problem domain characteristics. Marketing Intelligence and Planning, 23(4): 403-416.

Wamundila, S. (2008).Developing guidelines for a knowledge management policy to enhance knowledge retention at University of Zambia. Research Thesis, University of South Africa. 
Wamundila, S. \& Ngulube P. (2011). Enhancing knowledge retention in higher education: A case of the University of Zambia. SA Journal of Information Management, 13(1). doi: 10.4120/ sajim.v13i1.439

\section{Biography}

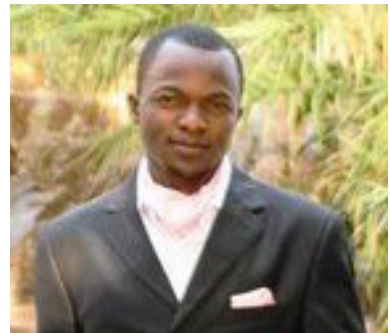

Nemwel N. Aming'a holds a Master of Arts in Knowledge Management from Kisii University where he works as a researcher. Most of his work entails proposal design, execution and management of research projects. His research interest revolves around knowledge dissemination and knowledge sharing in different settings including higher education institutions, elementary and high schools and business and farming enterprises. 